\title{
Діагностика ARS-синдрому у спортсменів
}

\author{
О. О. Коструб, Р. І. Блонський, В. Б. Заєць, \\ А. Я. Вовченко, І. М. Тютюнник
}

\author{
Державна установа «нститут травматології та ортопедії НАМН України», Київ, \\ Україна
}

\begin{abstract}
Резюме. Представлено теоретическое и практическое обоснование клинической, сонографической, а также магнитнорезонансной томографической картины ARS-синдрома у спортсменов.
\end{abstract}

Ключевые слова: ARS-синдром, диагностика, спортсмены.

\begin{abstract}
Summary. The paper presents theoretical and practical justification of clinical observations as well as results of sonography, computed tomography, and magnetic resonance imaging of AdductorRectus-Symphysis (ARS)-syndrome in athletes.

Keywords: ARS-syndrome, diagnosis, athletes.
\end{abstract}

Постановка проблеми. Сьогодні в Україні відбувається перехід від масового аматорського до високооплачуваного професійного спорту, що потребує формування якісно нового рівня фрункціональної готовності спортсменів. Намагання форсувати цей процес разом зі збільшенням фізичних навантажень, ускладненням технічних прийомів на тренуваннях, а також недосконалістю графіків змагань частіше призводить до патологічних станів, які рідко траплялися раніше. До них належить ARS-синдром.

За даними деяких авторів, $60 \%$ травм пахової ділянки у спортсменів становить ARSсиндром (Adductor-Rectus-Symphysis-Syndrom) $[6,7,9-12]$. Уперше його було описано болгарським лікарем М. Банковим [5]. Він означає ушкодження сухожильно-м'язового комплексу $\mathrm{mm}$. adductor longus et (or) brevis, m. gracilis, дистальної частини m.rectus abdominis, а також передньої частини $\mathrm{m}$. adductor magnus в місцях їх прикріпления до лобкової та (або) сідничної кістки, котрий виникає внаслідок хронічної мікротравматизації та перенавантаження опорнорухового апарату (OPA) в результаті невідповідності фрізичного навантаження, що виконує спортсмен на тренуванні, та можливістю компенсаторних реакцій організму. Дані причини призводять до ентезопатій, тендинітів та тендинозів локалізації з наступним їх мікро- або повним розривом, що веде до мікронестабільності переднього тазового півкільця, та набувають хронічного рецидивуючого характеру і проявляються локальною болючістю в ділянці лонного симфрізу з іррадіацією болю по внутрішній поверхні стегна, що підсилюється при активному приведенні стегна, а також під час виконання вправ для черевного преса (рис.1) [1].

Слід зазначити, що ефективність лікування ARS-синдрому на пізніх стадіях захворювання менша $[1,3,6,10]$, тому важливо заохочувати спортсменів дотримуватися правильної тренувальної програми та навчати їх звертатися за медичною допомогою при початкових проявах захворювання 3 метою ранньої діагностики та запобігання розвитку хронічного процесу $[1,3]$.

Методи та організація дослідження. Було обстежено 48 хворих з ARS-синдромом, які проходили лікування у відділенні спортивної та балетної травми ДУ «ІТО НАМНУ» у період з 2008 по 2012 рік. Всі пацієнти були спортсменами. До цієї категорії ми віднесли осіб, які щонайменше двічі на тиждень займаються відповідним видом спортивної діяльності (аматори), а також тих, для яких спорт $\epsilon$ професійною діяльністю. Середній вік $-28,4 \pm 4$ роки $(\mathrm{M} \pm \eta)$, серед них - чоловіків 40, жінок 8. Цей показник свідчить, що спортом найчастіше займаються чоловіки. За локалізацією права нижня кінцівка травмувалася частіше, ніж ліва, що становило в абсолютних числах 29, двостороння ентезопатія - 19 відповідно. Хворим з ARS-синдромом проводили клінічне, сонографрічне дослідження та магнітнорезонансну томограсрію.

Результати дослідження та їх обговорення. Оцінювання відповідності симптомів, притаманних для ARS-синдрому, проводили залежно від локалізації патологічного процесу та стадії захворювання. В таблиці 1 наведено абсолютну кількість симптомів залежно від локалізації та стадії патологічного процесу (Абс.), а також 

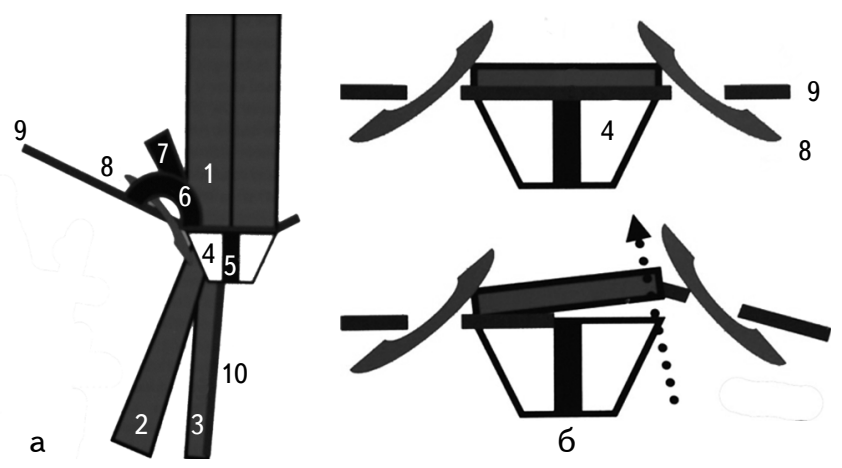

Рисунок 1 - Схематичне зображення пахової ділянки у фрронтальній (а) та горизонтальній площині (б) з механізмом развитку нестабільності навколо переднього тазового півкільця (вказано стрілкою) при ARS-синдромі: 1) прямий м'яз живота; 2) довгий привідний м'яз стегна; 3) тонкий м'яз стегна; 4) лонна кістка; 5) лобковий симоріз; 6) зовнішнє пахове кільце; 7) апоневроз косого м'яза живота; 8) сім'яний канатик; 9) паховий канал; 10) фрасція тонкого м'яза стегна

відсоток хворих при його локалізації та стадії захворювання (\%).

Таким чином, при гострій стадії захворювання (запалення) найінформативнішими клінічними симптомами були: локальна болючість при пальпації (100\%), болючого бігового прискорення $(90 \%)$ та болючого різкого випаду відповідної кінцівки в сторону (80\%). Слід зазначити, що вони не залежали від локалізації патологічного процесу. При цьому больовий синдром носив помірний характер та становивив 5-6 балів за ВАШ у $90 \%$ випадків, а сила відповідної групи м'язів при цьому суттєво не відрізнялася і становила 4-5 балів у $100 \%$ випадків.

При підгострій стадії захворювання (запалення) найінформативнішими клінічними симптомами були: локальна болючість при пальпації
(100\%), позитивний фрлексійний тест $(94,11 \%)$. Больовий синдром носив більш виражений характер та становивив 5-7 балів за ВАШ у приблизно $80 \%$ випадків.

При хронічній стадії захворювання (дегенерації) високу інфрормативність мали ті самі симптоми, що і на попередній стадії, зорема: локальна болючість, позитивний фрлексійний тест, болючого бігового прискорення, різкого випаду відповідної кінцівки в сторону, а інтенсивність больового синдрому та сила відповідної групи мязів суттєво не змінювались. Слід зазначити, що на даній стадії захворювання незалежно від локалізації патологічного процесу збільшилась питома вага таких симптомів як гіпотрофрія відповідної групи м'язів (понад 76,92 \%), фрлексійний тест на антагоністичну групу мязів (понад 69,23 \%).

На стадії дегенеративного розриву поряд із традиційними симптомами було відмічено суттєве зростання вираженості больового синдрому до 6-7 балів, при цьому сила привідних м'язів стегна знижувалася до 4 балів.

Сонографічне дослідження. Оцінку результатів сонографрічного дослідження було проведено після обстеження 48 хворих з ARS-синдромом.

Сонограсрічне обстеження виконували за допомогою апарата HDI-3500 (США) із мультичастотним лінійним датчиком за стандартною методикою.

При обстеженні оцінювали структурні характеристики сухожилля, а також ділянки їх переходу в кісткову тканину. Дослідження проводили на симетричних ділянках на здоровій та ураженій стороні в двох площинах. Датчик встановлювали вздовж сухожильно-кісткового переходу в симетричних ділянках, потім розвертали на $90^{\circ} \mathrm{i}$

ТАБЛИЦЯ 1 - Оцінка симптомів в у хворих з АРС-синдромом залежно від стадії захворювання

\begin{tabular}{|c|c|c|c|c|c|c|c|c|}
\hline \multirow{3}{*}{ Симптом } & \multicolumn{8}{|c|}{ Стадія } \\
\hline & \multicolumn{2}{|c|}{ 1-ша } & \multicolumn{2}{|c|}{ 2-га } & \multicolumn{2}{|c|}{ 3-тя } & \multicolumn{2}{|c|}{ 4-та } \\
\hline & Абс. & $\%$ & Абс. & $\%$ & Абс. & $\%$ & Абс. & $\%$ \\
\hline Локальна болючість при пальпації & 10 & 100 & 17 & 100 & 13 & 100 & 8 & 100 \\
\hline Позитивний фрлексійний тест на відповідну групу м'язів з протидією & 7 & 70 & 16 & 94,11 & 12 & 92,30 & 7 & 87,5 \\
\hline Позитивний фрлексійний тест на антагоністичну групу м'язів із протидією & 3 & 30 & 16 & 70,58 & 9 & 69,23 & 6 & 75 \\
\hline Гіпотрофія відповідного м'яза & 1 & 10 & 15 & 88,23 & 10 & 76,92 & 6 & 75 \\
\hline Болючого бігового прискорення & 9 & 90 & 16 & 94,11 & 11 & 84,61 & 7 & 87,5 \\
\hline Болючого різкого випаду відповідної кінцівки в сторону & 8 & 80 & 16 & 94,11 & 11 & 84,61 & 7 & 87,5 \\
\hline Болючого різкого випаду протилежної кінцівки в сторону & 2 & 20 & 11 & 64,70 & 7 & 53,84 & 1 & 12,5 \\
\hline Болючого покашлювання & 1 & 10 & 5 & 29,41 & 5 & 38,46 & 0 & 0 \\
\hline $\begin{array}{l}\text { Уявної короткочасної / стійкої (підкреслити) блокади в кульшовому } \\
\text { суглобі }\end{array}$ & 0 & 0 & 4 & 23,52 & 3 & 23,07 & 0 & 0 \\
\hline Уявної короткочасної / стійкої (підкреслити) блокади у колінному суглобі & 0 & 0 & 1 & 5,88 & 0 & 0 & 0 & 0 \\
\hline
\end{tabular}


ТАБЛИЦЯ 2 - Оцінка сонорафічних ознак у хворих з ARS-синдромом залежно від стадії захворювання

\begin{tabular}{|c|c|c|c|c|c|c|c|c|}
\hline \multirow{3}{*}{ Симптом } & \multicolumn{8}{|c|}{ Стадія } \\
\hline & \multicolumn{2}{|c|}{ 1-ша } & \multicolumn{2}{|c|}{ 2-га } & \multicolumn{2}{|c|}{ 3-тя } & \multicolumn{2}{|c|}{ 4-та } \\
\hline & Aбc. & $\%$ & Aбc. & $\%$ & Aбc. & $\%$ & Aбc. & $\%$ \\
\hline Осередки гіпоехогенності сухожилля & 0 & 0 & 5 & 29,41 & 12 & 92,30 & 2 & 25 \\
\hline Осередки анехогенності сухожилля & 0 & 0 & 0 & 0 & 3 & 23,07 & 8 & 100 \\
\hline $\begin{array}{l}\text { Осередки негомогенності сухожилля кальцифі- } \\
\text { катів }\end{array}$ & 0 & 0 & 17 & 100 & 12 & 92,30 & 1 & 12,5 \\
\hline Рідина навколо сухожиля & 7 & 70 & 5 & 29,41 & 9 & 69,23 & 1 & 12,5 \\
\hline $\begin{array}{l}\text { Нерівномірність кортикального шару в місцях } \\
\text { прикріплення сухожилля до кістки }\end{array}$ & 0 & 0 & 13 & 76,47 & 9 & 69,23 & 7 & 87,5 \\
\hline Кісткові екзостози & 0 & 0 & 8 & 47,05 & 12 & 92,30 & 5 & 62,5 \\
\hline Розширення пахових кілець & 0 & 0 & 1 & 5,88 & 2 & 15,38 & 0 & 0 \\
\hline Зміни навколо бурс & 0 & 0 & 5 & 29,41 & 0 & 0 & 0 & 0 \\
\hline Осередки гіперваскуляризації сухожилля & 9 & 90 & 1 & 5,88 & 0 & 0 & 0 & 0 \\
\hline
\end{tabular}

виконували сонографію в поперечнній площині та в доплерівському режимі.

При цьому оцінювали наявніть наступних сонографрічних ознак:

- осередки гіпоехогенності сухожилля;

- осередки анехогенності сухожилля;

- осередки негомогенності сухожилля кальцифрікатів;

- рідина навколо сухожилля;

- нерівномірність кортикального шару в місцях прикріплення сухожилля до кістки;

- кісткові екзостози;

- розширення пахових кілець;

- зміни навколо розташованих бурс.

У доплерівському режимі - наявність осередків гіперваскуляризації сухожилля.

Також проводили оцінку наявності згаданих ознак залежно від локалізації патологічного процесу та стадії тендинопатій. Отримані результати представлено в таблиці 2.

У ході оцінювання результатів сонографічного дослідження було виявлено ознаки тендинопатій, котрі залежали від строків перебігу патологічного процесу:

- у 10 хворих сонографрічна картина відповідала гострій стадії захворювання (від моменту дебюту клінічних проявів до 21-ї доби);

- у 17 хворих - підгострій стадії (від 21-ї доби до 3 місяців);

- у 13 хворих — хронічній (більше 3 місяців 3 моменту дебюту захворювання);

у 8 хворих було виявлено сонографрічні ознаки дегенеративного розриву (серед них $40 \%$ - частковий та $60 \%$ - повний).
Слід зазначити, що сонографічні ознаки тендинопатій на однакових стадіях захворювання мали однотипний характер, проте на кожній стадії можна відмітити певні, характерні саме для неї, особливості сонографрічної картини, за якою виділяли наступні стадії тендинопатій:

І. Гостра, або стадія запалення.

II. Підгостра, або стадія дистрофрії.

III. Хроніча, або стадія дегенерації.

IV. Дегенеративний розрив:

- частковий;

- повний.

При гострій стадії захворювання (запалення) на сонографічній картині у $90 \%$ хворих було відмічено ділянки посиленого судинного рисунка у $70 \%$ - наявність рідини навколо сухожилля (рис. 2).

При підгострій стадії (дистрофрії) під час сонографрічного обстеження поряд 3 ділянками посиленого судинного рисунка та наявністю рідини навколо сухожилля, було виявлено осередки негомогенності сухожилля (рис. 3).

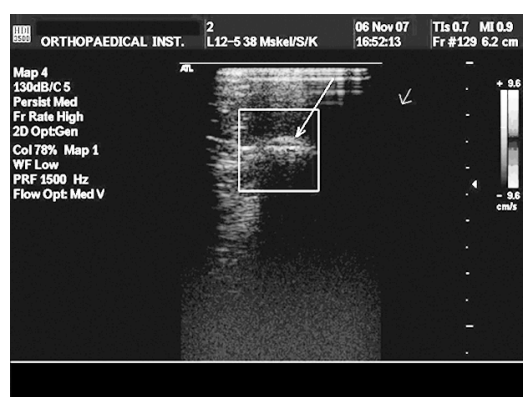

a

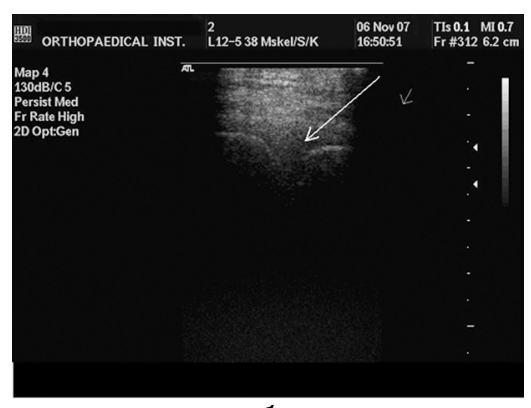

б
Рисунок 2 - Сонограми місць прикріплення сухожилля m. adductor longus та $\mathrm{m}$. rectus abdominalis:

a) посилення судинного рисунка на сухожиллі m. adductor longus; б) наявність рідини навколо сухожилля $\mathrm{m}$. rectus abdominalis 


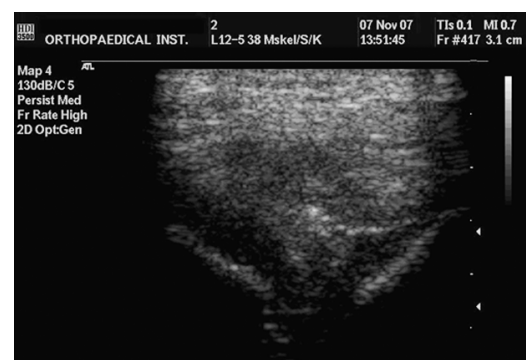

a

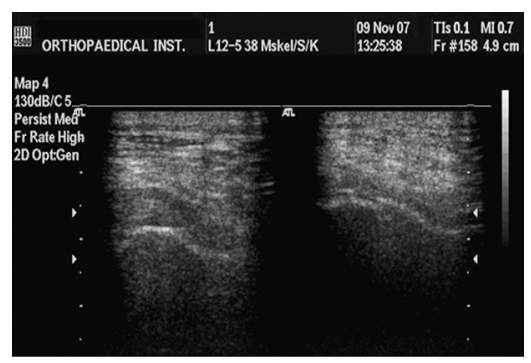

6

Рисунок 3 - Сонограми місць прикріплення сухожилля m. adductor longus et $\mathrm{m}$. rectus abdominalis:

a) ознаки негомогенності сухожилля $\mathrm{m}$. rectus abdominalis; б) ознаки негомогенності сухожилля m. adductor longus

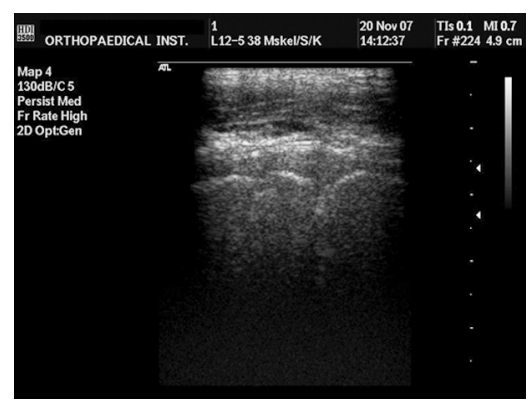

a

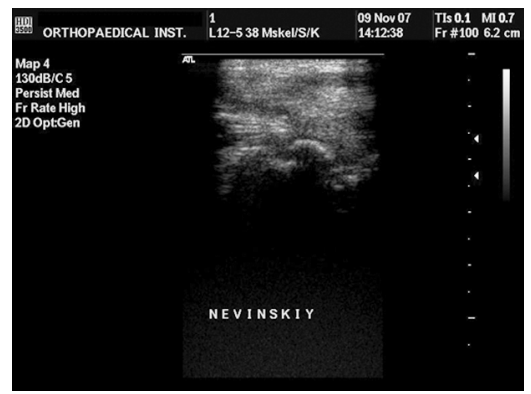

B

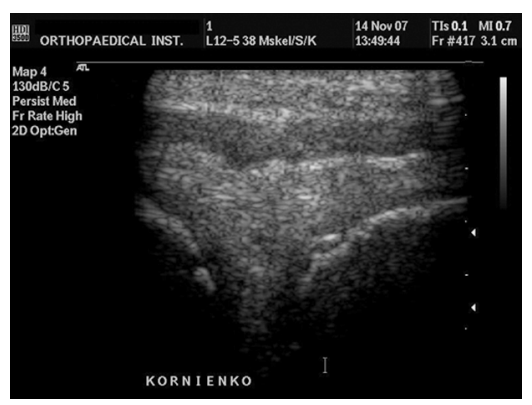

6

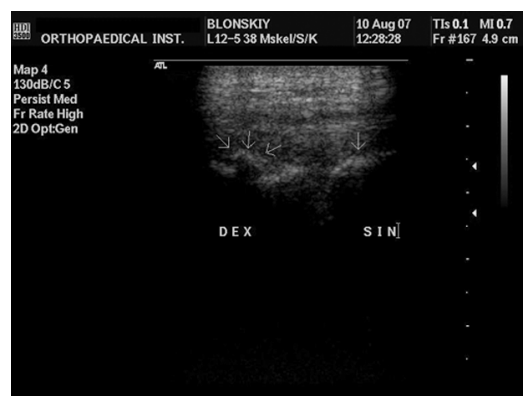

$\Gamma$

Рисунок 4 - Сонограми місць прикріплення сухожилля m. adductor longus et $\mathrm{m}$. rectus abdominalis:

a) осередки гіпоехогенності сухожилля m. adductor longus; б) кальцифікати сухожилля m. rectus abdominalis; в) нерівномірність кортикального шару в місцях прикріплення сухожилля m. adductor longus; г) кісткові екзостози сухожилля $\mathrm{m}$. rectus abdominalis

При хронічній стадії (дегенерації) сонографічна картина характеризувалася тим, що окрім ознак негомогенності сухожилля, а також рідини навколо них та місць їх прикріплення, спостерігали наявність наступних ознак та їхніх комбінацій (рис. 4):

- осередки гіпоехогенності та кальцифікатів сухожилля у 92,3 \% хворих;

- нерівномірність кортикального шару в місцях прикріплення сухожилля до кістки - у 69,3 \% хворих;

- кісткові екзостози у 92,3 \% хворих.

На сонографрічній картині стадії дегенеративного розриву поряд 3 описаними вище змінами, характерними для 3-ї стадії захворювання, та 3 ознаками дегенерації у $100 \%$ хворих визначали ділянки з анехогенними осередками (рис. 5). Якщо анехогенний проміжок проходив через усю товщу сухожилля, розрив вважали повним.

Отже, описана нами сонографрічна картина тендинопатій нижньої кінцівки характеризувалася поліморфністю проявів, що залежали від тривалості патологічного процесу, та відображала патофрізіологічні процеси, що відбуваються на відповідних стадіях захворювання.

МРТ дослідження. У ході дослідження було обстежено 13 хворих 3 ARS-синдромом. Усі пацієнти були спортсменами, середній вік - 27,4 року.

Обстеження пацієнтів проводили на магнітнорезонансному томографрі SIEMENS «MAGNETOM Avanto» $3 \mathrm{iH}^{-}$ дукцією магнітного поля 1,5 Тесла.

Виконували корональні, сагітальні та аксіальні томограми в режимах PD FS (протонної щільності $з$ пригніченням сигналу від жирової тканини), T1 WI (звичайні Т1 зважені).

Додатково було застосовано цифрову обробку стандартних МРТзображень у режимі PD FS за допомогою розробленої комп'ютерної програми, в якій різні відтінки сірого кольору перетворюються в різні колірні діапазони. Таким чином, поліпшується диференціація більш тонких змін сухожилля, оскільки різниця між різними відтінками сірого кольору оком вловлюється слабкіше, тоді як різниця між різними відтінками кольорової шкали більш чітко фріксується.

Найбільш інформативними в МРТ-діагностиці ентезопатій $є$ зображення з пригніченням сигналу від жирової тканини, виміряні за протонною щільністю (PD FS) та по T2 (T2 TSE FS), які високочутливі до рідини (гіперінтенсивний МРсигнал). Таким чином достовірно демонструються структурні зміни м'язів та сухожиль унаслідок запалення або ушкодження, що супроводжуються рідинною інфрільтрацією. Т1 виміряні зображення, звичайні (T1TSE) або з пригніченням 


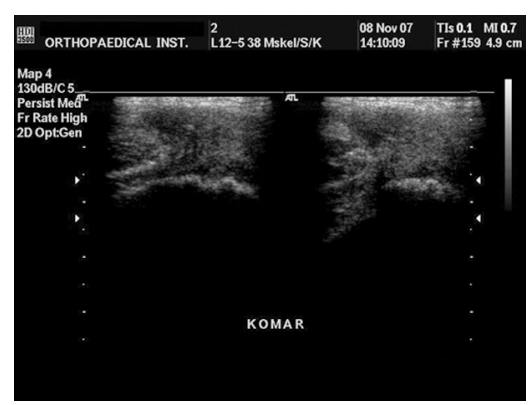

a

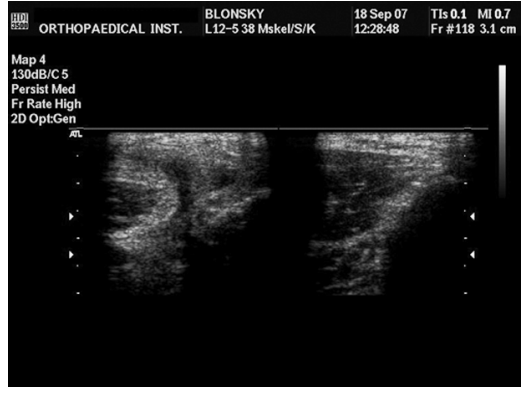

б

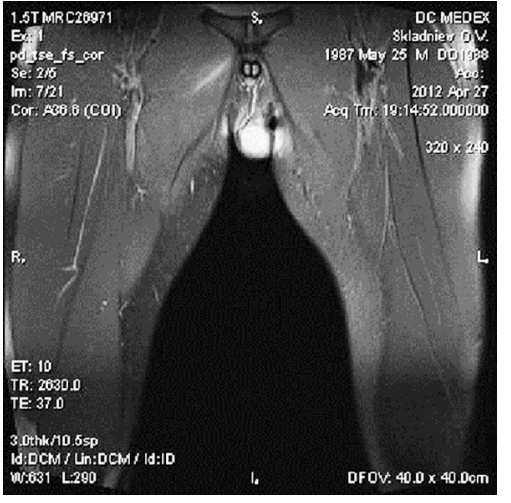

Рисунок 6 - МРТ-картина правостороннього ARS-синдрому: гостра стадія

а) анехогенні осередки при частковому розриві; б) анехогенні осередки при повному розриві

смуга в усіх режимах як на PD FS, так і на T1TSE) в зоні інсерції сухожилля.

При IV стадії (дегенеративного розриву) поряд зі змінами, що виявляються на попередніх стадіях, спостерігаються дефекти контуру сухожилля та переривання ходу частини волокон, що свідчить про частковий розрив, або повне його переривання, що може супроводжуватись виразним набряком оточуючих тканин.

Для поліпшення візуалізації патологічного процесу спільно з діагностичним центром «Медекс» розроблено метод кольорового картування зображень, що базується на цифровій обробці стандартних МРТ-зображень у режимі PD FS за допомогою розробленої комп'ютерної програми, коли різні відтінки сірого кольору перетворюються в кольорові діапазони, що дозволяє покращити діагностику патологічного процесу на ранніх стадіях захворювання, а також полегшити диференційну діагностику 3 іншими захворюваннями.

Також даний метод дозволяє полегшити диференційну діагностику тендинопатій нижньої кінцівки з іншими захворюваннями та патологічними станами.

Залежність МРТ-даних від стадії процесу при ARS-синдромі нижньої кінцівки представлено у таблиці 3.

Під час аналізу MPT-картини при ARS-синдромі основний патологічний процес протікав у місці кріплення сухожилля до кістки. Так, при другій стадії найчастіше спостерігали зниження інтенсивності МР-сигналу в кістці біля інсерції сухожилля, що відповідає запальному набряку кісткового мозку, нерівність кортикального шару - у 85,7 \% випадків; у третій стадії (дегенерації) - гомогенне дифрузне підвищення інтенсивності МР-сигналу від структури на PD FS та T1TSE, контур сухожилля нерівний, місцями ня кортикального шару (широка гіпоінтенсивна 
ТАБЛИЦЯ 3 - Залежність МРT-даних від стадії процесу при ARS-синдромі

\begin{tabular}{|c|c|c|c|c|c|c|}
\hline \multirow{3}{*}{ Симптом } & \multicolumn{6}{|c|}{ Стадія } \\
\hline & \multicolumn{2}{|c|}{ 2-ra } & \multicolumn{2}{|c|}{ 3-тя } & \multicolumn{2}{|c|}{ 4-та } \\
\hline & Абс. & $\%$ & Абс. & $\%$ & Абс. & $\%$ \\
\hline $\begin{array}{l}\text { Зниження інтенсивності MP-сигналу на T1TSE в кістці біля інсерції сухо- } \\
\text { жилля (гостра стадія) }\end{array}$ & 1 & 14,28 & 0 & 0 & 0 & 0 \\
\hline $\begin{array}{l}\text { Лінійно-дифузні ділянки гіперінтенсивного МР-сигналу в структурі сухо- } \\
\text { жилля (підгостра стадія) }\end{array}$ & 6 & 85,7 & 0 & 0 & 0 & 0 \\
\hline $\begin{array}{l}\text { Зниження інтенсивності МР-сигналу в кістці біля інсерції сухожилля з } \\
\text { нерівністю кортикального шару (підгостра стадія) }\end{array}$ & 5 & 71,42 & 0 & 0 & 0 & 0 \\
\hline $\begin{array}{l}\text { Гомогенне дифузне підвищення інтенсивності MP-сигналу від структури } \\
\text { на PDFS таT1TSE з нечіткими та переривчастими контурами сухожилля }\end{array}$ & 3 & 42,85 & 4 & 100 & 2 & 66,66 \\
\hline $\begin{array}{l}\text { Неоднорідність MP-сигналу від кісткового мозку та ущільнення корти- } \\
\text { кального шару (PDFS, так і на T1TSE) в зоні інсерції сухожилля }\end{array}$ & 1 & 14,28 & 4 & 100 & 0 & 0 \\
\hline $\begin{array}{l}\text { Дефекти контуру сухожилля та переривання ходу частини волокон (ста- } \\
\text { дія часткового розриву) }\end{array}$ & 0 & 0 & 4 & 100 & 2 & 66,66 \\
\hline Ознаки повного переривання ходу волокон (стадія повного розриву) & 0 & 0 & 0 & 0 & 1 & 33,33 \\
\hline Переривання контуру кортикального шару в зоні інсерції сухожилля & 0 & 0 & 0 & 0 & 2 & 66,66 \\
\hline Зміни навколо розташованих бурс & 0 & 0 & 0 & 0 & 0 & 0 \\
\hline Осередки кальцифікатів у ділянці сухожилля & 1 & 14,28 & 3 & 75,0 & 2 & 66,66 \\
\hline $\begin{array}{l}\text { Наявність кісткових остеофітів у ділянках, суміжних із інсерцією сухо- } \\
\text { жилля }\end{array}$ & 1 & 14,2 & 1 & 25,0 & 1 & 33,33 \\
\hline Набряк оточуючих тканин & 7 & 100 & 2 & 50 & 2 & 66,66 \\
\hline
\end{tabular}

нечіткий, неоднорідність МР-сигналу від кісткового мозку та ущільнення кортикального шару в зоні інсерції сухожилля у $100 \%$ випадків. На стадії розриву переривання контуру спостерігали як у ділянці сухожилля, так і в кортикальному шарі кістки ділянки реінсерції (66 \%).

Отже, виходячи з даних МРТ-дослідження, слід зазначити, що MPT-картина при ARSсиндромі залежала від строків патологічного процесу, а також повністю корелювала $з$ даними анамнезу, клінічного та інструментальних методів дослідження.

Відомо, що патологічний процес при тендинопатіях має однотипний характер і не залежить від локалізації патологічного процесу [11]. При цьому патофрізіологічні [4] та патанатомічні зміни в тканині сухожилля проявляються однотипними змінами в клінічній, сонографічній [2] та МРТкартинах [8], а також залежать від строків перебігу патологічного процесу:

- від моменту дебюту до 21-ї доби (гострий період);

- від 21-ї доби до 3 місяців (підгострий період);

\section{Література}

1. Коструб A. A. ARS-синдром: клиника, диагностика, лечение / А. А. Коструб, Р. И. Блонский // Спорт. медицина. - 2007. - № 3. - С. 90-95.
- від 3 місяців і більше (хронічний процес).

Виходячи зі сказаного, пропонуємо ввести робочу класифікацію тендинопатій нижньої кінцівки, що грунтується на базі анамнезу, клінічного, сонографічного, а також МРТ-досліджень.

І. Гостра стадія, або стадія запалення.

II. Підгостра стадія, або стадія дистрофрії.

III. Хроніча стадія , або стадія дегенерації.

IV.Дегенеративний розрив:

- частковий;

- повний.

\section{Висновки.}

Спираючись на отримані дані, розроблено робочу класифікацію, що дозволить систематизувати, своєчасно розпізнати даний патологічний процес та, виходячи 3 цього, розпочати своєчасне та адекватне його лікування.

Слід зазначити, що розроблений та впроваджений метод кольорового картування МРТ-зображень із метою діагностики тендинопатій нижньої кінцівки дозволяє покращити діагностику патологічного процесу на ранніх стадіях захворювання, а також полегшити диференційну діагностику з іншими патологічними станами чи захворюваннями.

\section{References}

1. Kostrub A. A. ARS-syndrome: clinical features, diagnosis, treatment / A. A. Kostrub, R. I. Blonskii // Sports medicine. - 2007. - № 3. - P. 90-95. 
2. Коструб О. О. Сонографрічна діагностика ентезопатій нижньої кінцівки / О. О. Коструб, Р.І.Блонський, А. Я. Вовченко, В. Б. Заєць. // Вісн. ортопед., травматол. та протезування. - 2008. - № 3. - С. 57-62.

3. ЛеВенець В. М. Спортивна травматологія: навч. посіб. для студ. вищих навч. закл. / В. М. Левенець, Я. В. Лінько. - К.: Олімп. л-ра, 2008. - 215 с.

4. Шойлев Д. Спортивная травматология / Д. Шойлев. - София, 1985. - С. 15-25.

5. Bankov M. / M. Bankov // La Medicine sportive: Travaux du XII Congres international de la medecine sportive, Moscou, 28 mai - 4 juin 1958. - Moscou: Édition en Langues Étrangères, 1960. - P. 502-504.

6. Guanche C. A. Hip and pelvis injuries in sports medicine / C. A. Guanche. - Philadelphia, PA: Lippncott Williams\& Wilkins, 2010.

7. Docinovic B. Surgical treatment of chronic groin pain in athletes / B. Docinovic, B. Sebecic // International orthopedics 2012; 36:2361-2367.

8. Effect of tendon orientation on MR imaging signal intensity: a manifestation of the «magic angle» phenomenon / S. J. Erickson, I. H. Cox, J. S. Hyde, G. F. Carerra // Radiology. - 1991. - Vol. 181. - P. 389-392.

9. Gilmore J. Groin pain in the soccer athlete: fact, fiction, and treatment / J. Gilmore. - Sports Med. - 1998. 17(4). - P.787-793, vii.

10. Jankovic S. The groin pain syndrome / S. Jankovic, D. Hudetz // Arh. Hig. Rada Toksikol. - 2001. - Vol. 52, N 4. - P. 421.

11. Maffuli N. Tendon injuries / N. Maffuli, P. Renstrom. - London: Springer, 2005. - P. 150-157.

12. Renstrom P. Groin injuries in athletes / P. Renstrom, L. Peterson // Br. J. Sports Med. -Vol. 14. - P. 30-61.
2. Kostrub O. O. Sonographic diagnosis of lower extremity enthesopathy / O. O. Kostrub, R. I. Blonskii, A. J. Vovchenko, V. B. Zaiets / / Visnyk ortopedii, travmatologii i protezuvannia. - 2008. - № 3. - P. 57-62.

3. Levenets V. N. Sports traumatology: Study guide / V. N. Levenets, Ya. V. Linko. - Kyiv: Olympic literature, 2008. $-215 \mathrm{p}$.

4. Shoilev D. Sports traumatology / D. Shoilev. - Sofia, 1985. - P. 15-25.

5. Bankov M. / M. Bankov // La Medicine sportive: Travaux du XII Congres international de la medecine sportive, Moscou, 28 mai - 4 juin 1958. - Moscou: Édition en Langues Étrangères, 1960. - P. 502-504.

6. Guanche C. A. Hip and pelvis injuries in sports medicine / C. A. Guanche. - Philadelphia, PA: Lippncott Williams\& Wilkins, 2010.

7. Docinovic $B$. Surgical treatment of chronic groin pain in athletes / B. Docinovic, B. Sebecic / / International orthopedics 2012; 36:2361-2367.

8. Effect of tendon orientation on MR imaging signal intensity: a manifestation of the «magic angle» phenomenon / S. J. Erickson, I. H. Cox, J. S. Hyde, G. F. Carerra / / Radiology. - 1991. - Vol. 181. - P. 389-392.

9. Gilmore J. Groin pain in the soccer athlete: fact, fiction, and treatment / J. Gilmore. - Sports Med. - 1998. 17(4). - P.787-793, vii.

10. Jankovic S. The groin pain syndrome / S. Jankovic, D. Hudetz // Arh. Hig. Rada Toksikol. - 2001. - Vol. 52, N 4. - P. 421.

11. Maffuli N. Tendon injuries / N. Maffuli, P. Renstrom. - London: Springer, 2005. - P. 150-157.

12. Renstrom P. Groin injuries in athletes / P. Renstrom, L. Peterson // Br. J. Sports Med. -Vol. 14. - P. 30-61. 